\title{
Deconcentration, Counter-Urbanization, or Trend Reversal? The Population Distribution of Switzerland, Revisited
}

\author{
Mulugeta S. Kahsai ${ }^{1}$ and Peter V. Schaeffer ${ }^{*}, 2$ \\ ${ }^{I}$ Post-doctoral Fellow Regional Research Institute West Virginia University Morgantown WV 26506-6825, USA \\ ${ }^{2}$ Division of Resource Management and Faculty Research Associate Regional Research Institute West Virginia \\ University Morgantown WV 26506-6108, USA
}

\begin{abstract}
This study analyzes trends in the population distribution of Switzerland, with focus on the period 1980-2000. It updates and extends an earlier study [1]. The extensions include analyses of population distribution trends by region and citizenship. Results show that Switzerland experienced deconcentration in the 1970s at the cantonal level, and in the 1980s and 1990s at the district level. The results also show a trend of moving away from large densely populated districts to small, sparsely populated and medium sized districts. There was a strong suburbanization trend starting in the $1950 \mathrm{~s}$ and counter-urbanization during 1980-2000. The core urban areas experienced the slowest growth at the end of the century. Although the foreign permanent resident population increased from $11.6 \%$ at the beginning of the century to $20.7 \%$ in 2005 , its role in shaping the distribution pattern is low.
\end{abstract}

Keywords: Population distribution, urbanization, counter-urbanization, deconcentration, trend reversal, suburbanization, power of topography, metropolitan regions, peripheral regions.

\section{INTRODUCTION}

The world's population distribution has been changing for a long time [2]. A majority of the world's population became urban only in 2007 and urbanization trends remain strong in most developing nations. Changes are also occurring in the world's industrialized countries where suburbanization followed the initial urbanization to central cities. More recently ex-urban development and growth at the urban-rural fringe have attracted attention [3] although the concept of the urban-rural fringe dates back to at least 1942 [4]. Urbanization also affects rural regions as some of them lose population and with it economic and political influences $[5,6]$.

New demographic developments in the 1980s, first noticed in the United States, which showed that for a while at least, rural areas grew at a faster pace than urban areas, led many authors to study population distribution trends in industrialized countries [1, 7-21]. It was not clear if the new development was a reversal of the historic trend from a predominately rural to a predominately urban society, or if it was a case of continued but less concentrated urbanization, or if it was a case of urban decentralization [22, 23]. Any of these developments could have resulted in faster growth in regions categorized more rural, than in urban ones. Bourne [24] early on commented on the complexity of the theoretical issues involved. One reason is that not so long ago some of today's urban regions were classified as rural; that is, many of the fastest-growing rural regions are no

*Address correspondence to this author at the Division of Resource Management and Faculty Research Associate Regional Research Institute West Virginia University Morgantown WV 26506-6108, USA; Tel: 304293-5572; E-mail: Peter.Schaeffer@mail.wvu.edu longer counted toward the success of rural economies and society ${ }^{1}$.

In recent years, the questions have changed again, as there is little evidence of a lasting trend reversal, while the population is stagnating or declining in many remote rural areas in the developed world. The spatial distribution of populations in emerging economies, such as China [25, 26] and Brazil [27], attract much attention, but new studies are also conducted in the most industrialized countries, such as the Netherlands [28] and the United States [29]. There is even more "induced" research, particularly in rural economies of advanced nations, because of their stagnation relative to urban areas (e.g., for the United States, see Center for the Study of Rural America, [30]; for OECD countries, in general, see OECD, $2006^{2}$ [31]).

The terms deconcentration and counter-urbanization are sometimes used interchangeably to describe trends in population movement away from large urban centers. However, a few authors $[11,21,32]$ defined these two concepts as different population distribution patterns, and there is still inconsistency in their use [32]. In this study we define the two terms as meaning somewhat different things.

\section{SWITZERLAND}

This research looks at Switzerland, a country that has been economically strong and stable, and whose population has been growing, though at a slow pace. The overall stability hides several important changes, however, namely the effects of an aging population and of a changing

\footnotetext{
${ }^{1}$ We owe this insight to Andrew Isserman University of Illinois at UrbanaChampaign.

${ }^{2}$ The OECD also organizes an annual rural policy conference. The last meeting was held October 2009 in Quebec City Canada. See www.oecd.org/gov/ruraldevelopment for more information.
} 


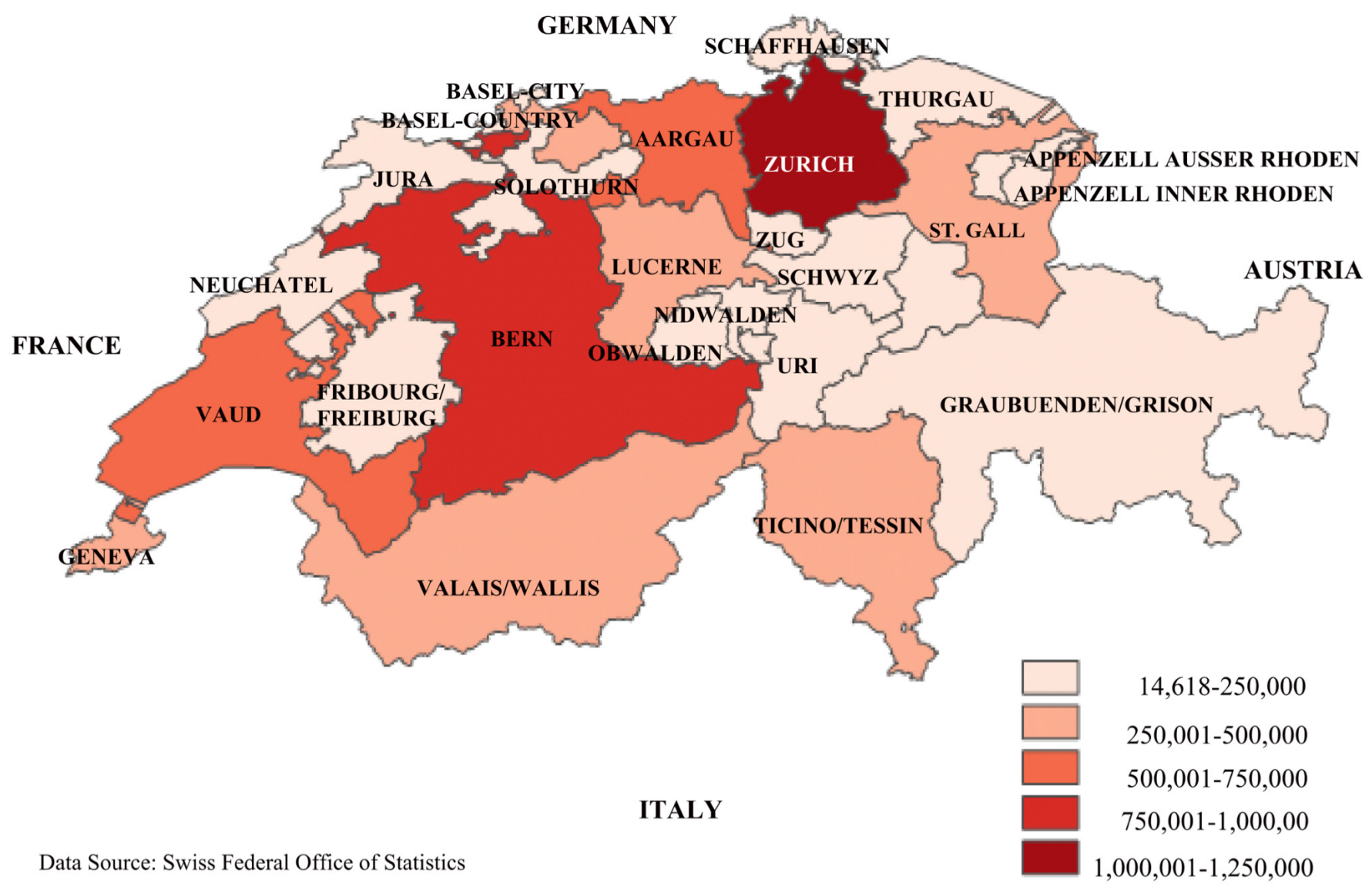

Fig. (1). Map of Switzerland and its Cantons ${ }^{4}$.

immigrant population. The foreign-born ${ }^{3}$ population accounts for more than 20 percent of the total population. Important changes occurred in this population between 1950 and 2000 as the number of foreign residents with permanent $v s$ those with annually renewable visas and work permits grew [33]. Unlike permanent visas annual visas usually come with location and employment constraints. In addition, there have been great changes in the make-up of industries, with employment in services growing and declining in manufacturing, changes that could significantly affect population and commuting patterns.

Fig. (1) shows a map of Switzerland and its cantons. Cantons are the largest sub-federal political entities and play the role of states in the United States. The next level is that of districts, which are roughly equivalent to counties, and then the communities. Unlike in the United States, the territories of the communities cover all of Switzerland; there are no unincorporated areas. The map shows that Zurich is the most populous canton followed by the Canton of Bern, while peripheral cantons such as Jura, Neuchatel, and Graubünden (Grisons, largest canton by land area) are among the smallest and most rural. The map in Fig. (2)

\footnotetext{
${ }^{3}$ The immigrant population is smaller than the foreign-born population because the latter includes individuals born in Switzerland. Unlike the United States and many other countries Switzerland does not automatically award citizenship to those born within its territory.

${ }^{4}$ We thank Mrs. Jacquelyn Strager for help preparing the maps. The maps rely on information from the Swiss Federal Office for Statistics.
}

shows population densities (by district), which further show the concentration of the population on the pre-alpine plateau.

Switzerland is an interesting case study because of its terrain. Most of the population is concentrated in the prealpine region (Swiss Plateau), which has excellent infrastructure and is easily accessible, while most settlements in the mountainous alpine and Jura regions are considerably less accessible (resulting regional policy concerns are explained in [34]). The two mountain regions account for some $60 \%$ of Switzerland's land area. Fig. (2) presents a map of population densities in Switzerland in 1850, 1900, 1950, and 2000. The map illustrates that the northern metropolitan regions, particularly Zurich, have grown the most, while the population densities even in affluent peripheral areas have not changed much $^{5}$.

The map in Fig. (3) shows that the Zurich MSA has grown to encompass the once isolated Winterthur MSA and that its sphere of influence extends far into neighboring cantons. Thus, a good part of the population growth in the Canton of Schwyz (south of Zurich) can be explained by the suburbanization of communities in that canton, particularly those located on National Highway 3, as the Zurich MSA expanded. These communities enjoy excellent commuter train connections to the central city and other large communities within the MSA, which facilitates cross-

${ }^{5}$ For example population density in the Engadin which includes St. Moritz and several smaller resort towns has not changed much over the last fifty years. 
Average Density

77.8 inhabitants/square $\mathrm{km}$
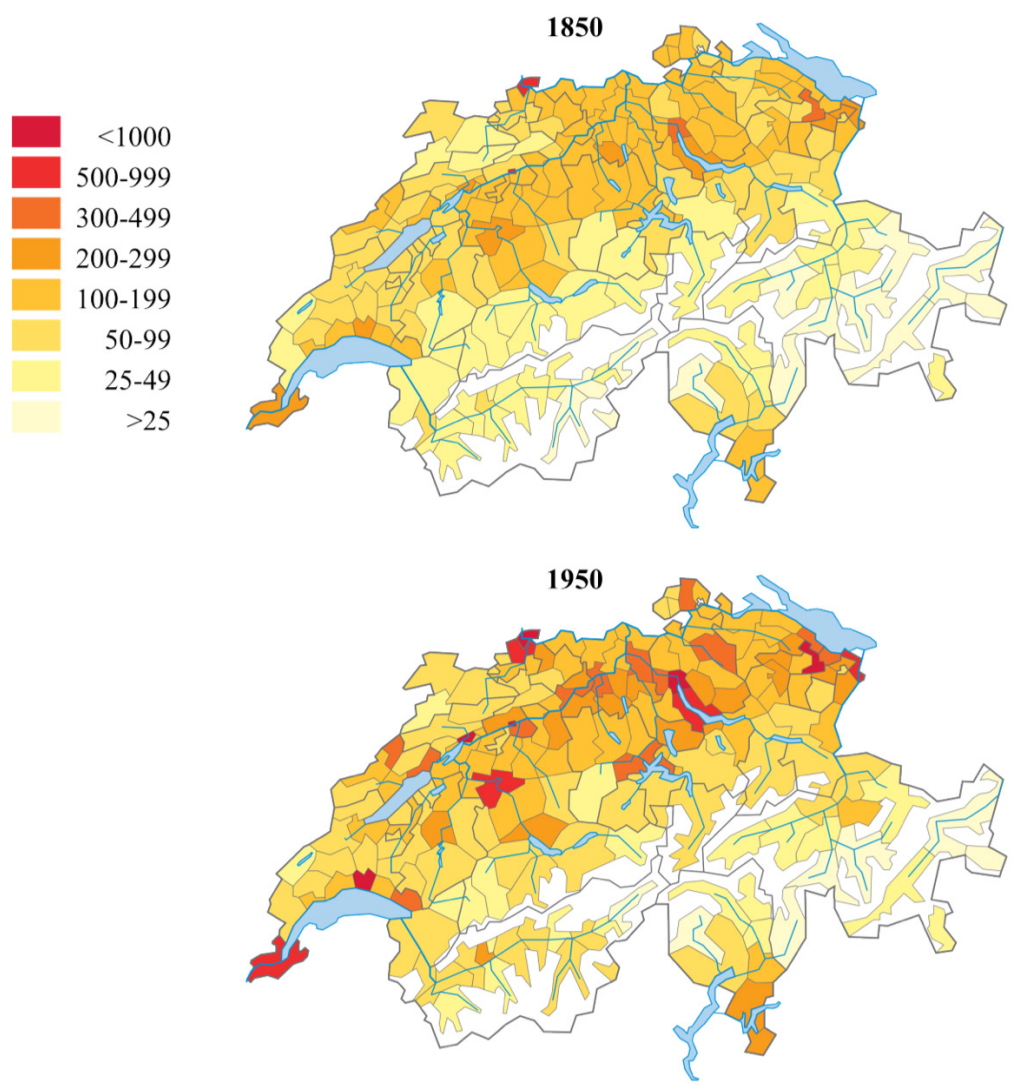

Average Density

153.3 inhabitants/square $\mathrm{km}$
Average Density

107.8 inhabitants/square $\mathrm{km}$
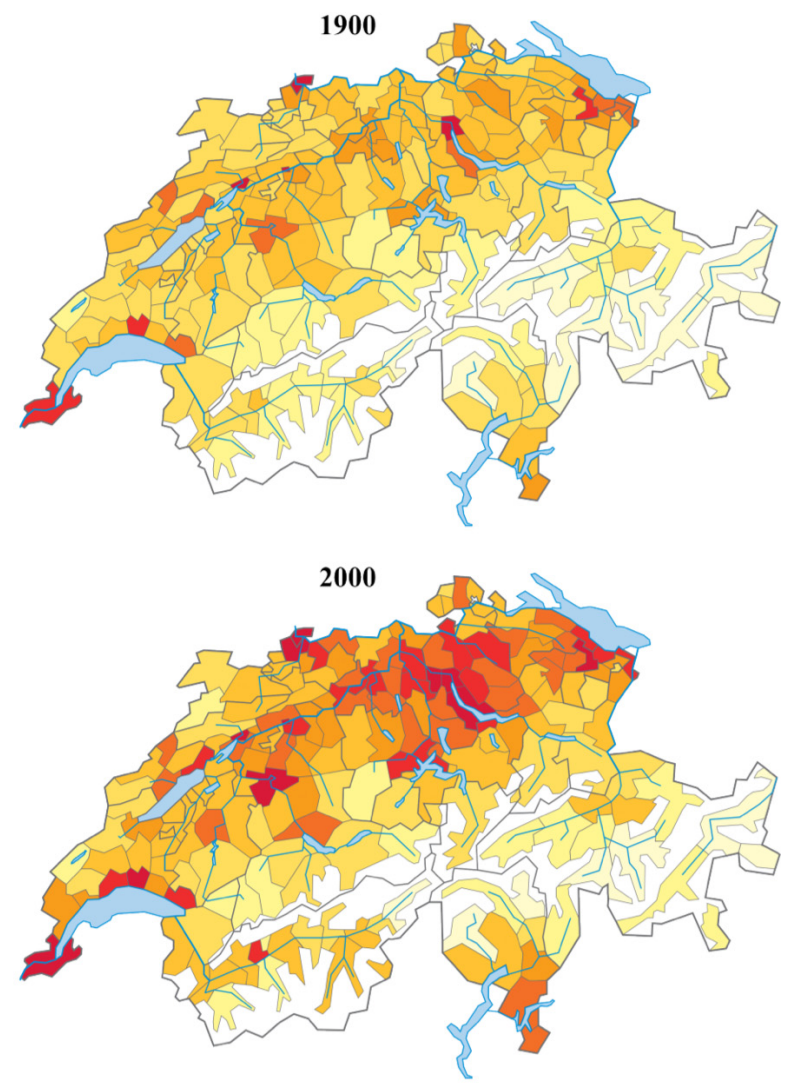

Average Density

237.0 inhabitants/square $\mathrm{km}$

Fig. (2). Population Densities by District 1850, 1900, 1950, and $2000^{6}$.

commuting. Although the cities of Lucerne and Zug have not yet completely grown together with the Zurich MSA, they are in Zurich's sphere of influence and a commuter train ride from the center of Lucerne to the center of Zurich only takes about one hour and less than one hour, from the city of Zug (see map in Fig. 3). Because of the strong interrelationships, Glanzmann et al. [35] refer to the urban areas contained within the triangle defined by Basel, Lucerne, and St. Gall as the "European Metropolitan Region of North Switzerland".

Swiss Federal Planning Law [36] has as one its goals the promotion of a "reasonably" decentralized population and economy (Article 1.c $\mathrm{c}^{7}$ ). In addition to efficiency concerns-when towns decline infrastructure is often left underutilized-this goal also has a political dimension. In a multiethnic federal country such as Switzerland ${ }^{8}$, large

${ }^{6}$ Figure 2 is a slightly edited version of a map from the Swiss Federal Office for Statistics

http://www.bfs.admin.ch/bfs/portal/de/index/regionen/thematische_karten/m aps/bevoelkerung/bevoelkerungsstand/0/bevoelkerungsstand.parsys.0005.Ph otogalleryDownloadFile3.tmp/k01.86s.pdf.

${ }^{7}$ The federal cantonal and local governments support efforts ....to promote the social economic and cultural life in the different regions of the country and to achieve a reasonable (angemessene could also be translated as "appropriate") decentralization of population and economy. (Summarized and translated by authors.)

${ }^{8}$ Switzerland has four national languages. German speakers constitute the largest group followed by French and Italian speakers. The fourth language population shifts from one language region to another or from traditionally agrarian to long-established urban societies could threaten political balance and peace. The Swiss federal government has therefore designed programs to help lagging areas. One example was the Swiss Federal Law on Investment Aid in Mountain Regions (original law of June 28, 1974, revised March 21, 1997) which provides assistance for infrastructure investments in Swiss mountain regions. A new law on regional policy replaced it in 2006 and broadened the geographic coverage of the law by abandoning the exclusive focus on mountain regions. The new law focuses more generally on regional competitiveness and includes provisions for cross-border cooperative efforts [37, 38]. Flückiger, Frey, and Gmünder [39] provide additional detail concerning challenges and changes in land use planning and regional policy in Switzerland at the advent of the new century.

Fig. (3) shows even more clearly that Switzerland's five metropolitan areas (Basel, Bern Geneva-Lausanne, Tessin (Ticino), and Zurich) developed around the largest historic cities Zurich, Basel, Geneva, Bern, and Lausanne. Chiasso, at the southern tip of Switzerland, is a community that has benefitted from its location at the border to Italy by

Romansh is spoken only by a very small minority in the Canton of Grison (Graubünden). 


\section{GERMANY}

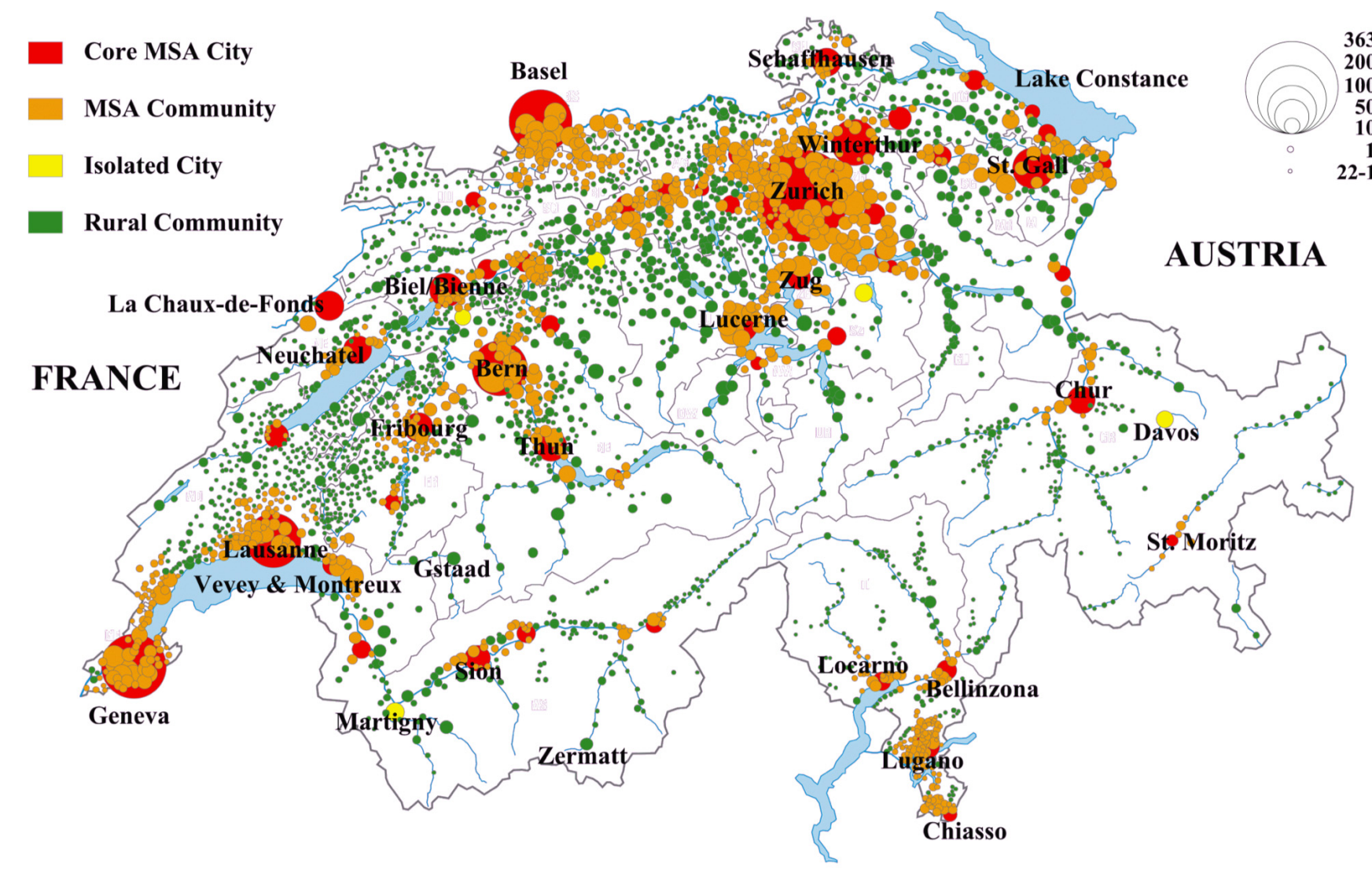

\section{ITALY}

Fig. (3). Population by Community $2000^{9,10}$.

becoming a banking center for Italian customers, and Bellinzona is the capital of the Canton of Tessin. Unlike in some other countries, Switzerland's general pattern of the population distribution did not change much over the last 150 years. There was no population shift to the west or south, such as it occurred in the United States, in spite of rapid industrial growth in the late $19^{\text {th }}$ century, and significant industrial restructuring in the second half of the twentieth century. Language is one likely reason for the stability of the population distribution, since the north is German, the southwest French, and the south is Italian speaking, although high immigration during the late $19^{\text {th }}$ and the early $20^{\text {th }}$ century, and in second half of the $20^{\text {th }}$ century, contributed significantly to population growth. The second likely reason is topography, clearly visible in Fig. (3), which limits large developments to the Swiss Plateau and mountain valleys. Thus, the maps show that the largest metropolitan areas have gained demographic and economic clout relative to more peripheral cantons and regions.

${ }^{9}$ We use the term MSA (Metropolitan Statistical Area) that is common in the United States to designate what the Swiss Federal Office for Statistics calls "Agglomeration". The Swiss Federal Office for Statistics in 1990 established the following five official metropolitan areas: Basel Bern Geneva-Lausanne Tessin (Ticino) and Zurich.
At least three border metro regions-Basel (Germany and France), Geneva (France), and the southern part of the Canton of Tessin (Italy) -have economies that are integrated with those of their foreign neighbors. This is evidenced, for example, by the very large number of daily border-crossers and, in the case of Basel, a shared airport with the French city of Mulhouse.

This research builds on Schaeffer [1] and highlights changes between 1970 and 2000. However, we include information dating back to 1900 to track changes that came with then relatively new industrialization and urbanization trends, as well as changes caused by large infrastructure investments, such as the construction of a series of alpine train lines and tunnels, automobile tunnels, and the development of a national highway system (Autobahn). This study will assess whether the population distribution trend of the $1970 \mathrm{~s}$ continued until the end of the $20^{\text {th }}$ century.

\footnotetext{
${ }^{10}$ Fig. (3) has been adapted from a map provided by the Swiss Federal Office for Statistics (SFOS)

http://www.bfs.admin.ch/bfs/portal/de/index/regionen/thematische_karten/m aps/bevoelkerung/bevoelkerungsstand/0/bevoelkerungsstand.parsys.0003.Ph otogalleryDownloadFile4.tmp/k01.89s.pdf Additional maps of potential interest to the reader can be accessed from the SFOS website at http://www.bfs.admin.ch/bfs/portal/de/index/regionen/thematische_karten/m aps/bevoelkerung/bevoelkerungsstand/0/bevoelkerungsstand.html. Explanations are usually limited to French and German.
} 
Specifically, we will answer the following questions: (1) Is Switzerland's population concentrating or deconcentrating? (2) What are the effects of regional differences? (3) Is there any trend toward counter-urbanization? And, finally: (4) is there any indication of trend reversal?

The remainder of this article is organized into four sections. In the next section we will introduce the measures of population distribution patterns used in this research. Section 3 describes the data. Results are presented in Section 4. Section 5 concludes the article with a summary and discussion of findings.

\section{MEASURES OF POPULATION DISTRIBUTION PATTERNS}

\subsection{Deconcentration}

Deconcentration is defined as slower population growth in areas with above average density than in areas with below average density. The standard measure used in the literature is the Hoover index $\left(H_{i t}\right)$.

$H_{i t}=\frac{1}{2} \sum_{i=1}^{N}\left|P_{i t}-A_{i}\right| 100$

$N$ is the number of regions that completely cover the country and are mutually exclusive. The variables $P_{i t}$ represent the proportion of the country's population residing in region $i$ at time $t$, and $A_{i}$ is the proportion of the country's area covered by region $i$. The index is 0 if, in every region $i$, the shares of the country's population and of the country's territory are identical (perfect deconcentration). The measure approaches 100 if everyone lives in just one area which is small in size (perfect concentration). Thus, high values of $H_{i t}$, indicate a very uneven population, distribution, and vice versa. Clearly, the choice of geographic unit of analysis affects the value of $H_{i t}$ as the index is 0 if the unit of analysis is the whole country.

One of the extensions by Long and Nucci [21] is to calculate separate indexes for the sub-regions of the United States, in addition to the national index. This allows checking for the existence of different patterns in different regions. In a multi-cultural federal county like Switzerland, the nature of change in the population distribution among different regions is of great interest as Swiss cantons vary by official language, cultures, geographic features, economic structure, and degree of urbanization. All these characteristics may have some impact on migration patterns and should therefore be taken into account.

\subsection{Counter-Urbanization}

Counter-urbanization is the reversal of the long trend towards more and larger urban settlements. It is a process of settlement system change. Counter-urbanization is thus seen as occurring when population growth in areas with small populations exceeds that in large population centers [40]. This definition is compatible with that proposed by Champion and Fielding $[9,10]$. But other definitions used in the literature (e.g. Berry) [41] do not differentiate between counter-urbanization and population deconcentration, and define counter-urbanization as a process of population deconcentration which implies a movement from a state of more concentration to a state of less concentration. The relationship between the size of a settlement or region and net migration has also been employed in the literature $[10$, $15,16]$. In this study, we use the relationship between population density and growth per square kilometer $\left(\mathrm{km}^{2}\right)$.

\subsection{Trend Reversal}

Trend reversal exists if the population distribution becomes more similar to that of the past. Therefore, we compare the percent of a country's population living in a region, $i$, in base year, 0 , and in an ending year, $t$. We use the average of the absolute differences by region as our measure $T R_{0, t}$. Trend reversal exists if $T R_{0, t}$ declines.

$$
\begin{aligned}
T R_{0, t}=\sum_{i=1}^{N} & \frac{1}{N} \mid \frac{\text { Population in region } i \text { in base year }(0)}{\text { Population in Switzerland in base year }(0)} \\
& -\frac{\text { Population in region } i \text { in year }(t)}{\text { Population in Switzerland in year }(t)} \mid
\end{aligned}
$$

As before, $N$ stands for the number of regions. It is worth noting that, given Switzerland's rural past, trend reversal implies counter-urbanization, but that the reverse is not true.

\section{DATA}

The population data used in our study is from the decennial censuses of Switzerland from 1900 to 2000 (Swiss Federal Office of Statistics/Bundesamt für Statistik, various years ${ }^{11}$ ) [42]. The war-time census of 1940 was delayed and taken in 1941. Population figures after 2000 are available, but they are based on a different procedure than that used in the census. Although we do not expect large discrepancies, we judge the potential for error large enough not to use the newer data. Thus, the focus of the analysis is the period 1970-2000. This study builds on Schaeffer's [1] research and checks if trends he identified-deconcentration and minor counter-urbanization in the 1970s-continued between 1970 and 2000. We also take a look at the influence of the foreignborn on the population distribution.

The geographic subdivisions used in our analysis are the cantons (26) and districts (175), respectively. Cantons are the functional equivalent of states, though they have the territorial size of counties and the districts' functions are comparable to those of a county in the United States, though with less power ${ }^{12}$. The change in population in cities with more than 30,000 residents is assessed to supplement the district level analysis. We grouped the 175 Swiss districts into the seven main regions ${ }^{13}$, as defined by the Swiss

\footnotetext{
${ }^{11}$ The Swiss Federal Office of Statistics grants access to the data via the World Wide Web for a fee of approximately $\$ 50$ year.

${ }^{12}$ Swiss communities occupy a much stronger political position than counties. Communities cover all of Switzerland. Unlike in the United States, there are no unincorporated areas where the county is the prime provider of local public services. Hence, Swiss districts play a very limited role.

${ }^{13}$ The regions are:

Lake Geneva Region: Geneva, Vaud, Valais, regional cities: Geneva and Lausanne

Espace Mittelland: Bern, Jura, Neuchatel, Fribourg, Solothurn; regional city: Bern
} 
Federal Office of Statistics. This permits the comparison of regional concentration/deconcentration during the study period.

More than 70 percent of Switzerland is covered by the Alps in the central and southern region,s and the Jura mountains along its western border with France. The Swiss Plateau is a hilly pre-alpine basin that stretches from Geneva in the southwest across most of northern and central Switzerland, to Lake Constance in the northeast. Switzerland's largest towns are located on this plateau. The country's population is very unevenly distributed, with nearly 90 percent living on the Swiss Plateau. An estimated 70 percent of the population is classified as urban, but most people live in small towns. There are only 17 cities with a population of at least 30,000 . The country's total population in 2000 was $7,204,100$ of which $5,77,9700$ were Swiss citizens and 1,424,400 were foreign nationals. Thus, Switzerland hosts a large and growing foreign-born population: $16.7 \%$ in $1990,19.2 \%$ in 2000 , and $20.7 \%$ in 2005. The distribution of foreign nationals does not follow the same pattern as that of Swiss citizens. In general, urban areas have a higher concentration of foreign nationals, but there are exceptions, such as the rural and mountainous Canton of Glarus. The high percentage of foreign nationals in this canton cannot be explained by the needs of the tourism sector, since it is not one of the major tourist destinations.

The rate of natural population growth in Switzerland is low, as in most of Europe. Thus, net international migration is the major growth engine, even more so if we also consider children born to foreign residents. The immigrant population grew from $11 \%$ in 1900 to $20.7 \%$ in 2005 . The majority of immigrants are from European countries. Traditionally they came mainly from Italy and later also from Spain, but the fall of the Iron Curtain also brought an increasing number of immigrants from Eastern Europe, particularly the countries of the former Socialist Republic of Yugoslavia. In the most recent years, German immigration has grown to where Germans are the largest single group of immigrants in several regions. These groups of immigrants are culturally close to the native population and language affinity affects location patterns of immigrants. For example, the vast majority of Portuguese immigrants settled in the French speaking part of Switzerland. Immigration from outside Europe has also been increasing. Because there are no reasons to assume that the distribution pattern of immigrants follows the same pattern as that of the native Swiss, the Hoover Index for Swiss citizens and immigrant permanent residents is calculated separately and compared at the cantonal level.

Switzerland is $41,293 \mathrm{~km}^{2}$ (15,734 sq. miles) in size. However, in this study we will use only the $39,995 \mathrm{~km}^{2}$ of land area. The average size of a canton is $1,588 \mathrm{~km}^{2}$ (605 sq.

Northwestern Switzerland: Basel-City, Basel-Country, Aargau; regional city: Basel-City

Zurich: (Canton of) Zurich; regional city: Zurich

Eastern Switzerland: St. Gall, Glarus, Schaffhausen, Appenzell I.R., Appenzell A.R., Grisons, and Thurgau; regional city: St. Gall

Central Switzerland: Zug, Lucerne, Uri, Schwyz, Obwalden, and Nidwalden, regional city: Lucerne

Ticino: Canton of Tessin; regional city: Lugano miles). However, there are large differences in size between cantons: the population of Zurich is almost 100 times that of Appenzell Innerrhoden, and Grison has 192 times of the land area of Basel-City. For this study, the Canton of Geneva has been divided into the City of Geneva and the "rest of the canton". Because the Canton of Geneva is also the District of Geneva, as a result of splitting off the city we have 176 entities at the district level.

\section{TRENDS IN POPULATION DISTRIBUTIONS}

\subsection{Deconcentration}

The values of the Hoover Index for cantons show that the concentration of the population of Switzerland increased steadily between 1900 and 1970. During the ten years from 1970 to 1980, however, the Hoover Index decreased and then increased again until 2000. The contribution of each canton to the changes in the index is a function of its successive differences between its proportion of national population and land share, respectively. Since the share of land was fixed during the study period, the changes are due to growth or decline in the share of national population.

Table 2 shows the contributions of selected cantons to the change of the Hoover index. In the 1970s, the Hoover Index declined by -0.18 , showing a clear indication of deconcentration. During that period, 14 cantons made positive contributions to the change of the Hoover Index and 12 cantons made negative contributions. The most notable negative contribution came from Basel-City, where the national share of the population decreased by $0.54 \%$, resulting in a contribution of -0.27 to the decrease of the Hoover Index. This canton lost more than 31,000 people while the country was growing at the rate of $1.53 \%$. Bern, Aargau, and Geneva were the major positive contributors to the index, as their share of the national population was increasing. Zurich, the most populous canton (17.64\% of Swiss population in 1980 and $4.15 \%$ of the land area) made a small negative contribution. Schaeffer [1] noted, "In a small country there is a greater danger that one or a few regions have a disproportionate weight in the calculation of the Hoover index" (p. 92). Although in percentages, the population decline of Bern was higher than the decline of Zurich for the entire three decades (Table A1), Bern was able to contribute positively to the index. This indicates the strong influence of Zurich on the index due to the large difference between its population shares relative to its share of the land.

In the 1980s and 1990s, the index increased by a small amount indicating modest renewed concentration. The major contributors in the 1980 were the same as during the 1970s. The contributions of Zurich and Basel-City were negative while Bern, Aargau, and Vaud were the major positive contributors. Geneva made a small positive contribution and the rest of the cantons had a negative impact on the Hoover Index. During the 1990s, of the most populous cantons only Bern continued to make a strong positive contribution. Geneva's positive contribution, though significantly smaller, had increased close to its contribution during the 1970s, after having dropped to a low 0.02 during the 1980 s. The opposite roles as negative and positive contributors, respectively, during the thirty year period played by the most populous cantons of Zurich, Bern, Vaud, Basel-City, and Geneva makes for an interesting contrast. These cantons contain not 
Table 1. Hoover Index for Cantons Districts and Regions 1900-2000

\begin{tabular}{|c|c|c|c|c|c|c|c|c|c|}
\hline (1) & (2) & (3) & (4) & (5) & (6) & (7) & (8) & (9) & (10) \\
\hline Year & $\begin{array}{c}\text { HI All } \\
\text { Cantons }\end{array}$ & $\begin{array}{c}\text { All } \\
\text { Districts }\end{array}$ & $\begin{array}{c}\text { Lake Geneva } \\
\text { Region }\end{array}$ & $\begin{array}{c}\text { Espace } \\
\text { Mittelland }\end{array}$ & $\begin{array}{c}\text { Northwestern } \\
\text { Switzerland }\end{array}$ & Zurich & $\begin{array}{c}\text { Eastern } \\
\text { Switzerland }\end{array}$ & $\begin{array}{c}\text { Central } \\
\text { Switzerland }\end{array}$ & Ticino \\
\hline 1900 & 31.56 & 41.22 & 45.67 & 29.00 & 28.89 & 36.84 & 48.04 & 30.46 & 40.38 \\
\hline 1910 & 32.21 & 42.54 & 45.75 & 29.76 & 31.16 & 40.20 & 49.50 & 31.76 & 43.01 \\
\hline 1920 & 32.72 & 43.28 & 48.14 & 31.18 & 31.92 & 40.75 & 49.18 & 32.44 & 43.26 \\
\hline 1930 & 33.01 & 44.26 & 48.00 & 32.49 & 33.58 & 43.97 & 47.88 & 33.46 & 44.09 \\
\hline 1941 & 33.07 & 44.99 & 48.43 & 33.78 & 34.59 & 46.23 & 47.49 & 33.11 & 44.58 \\
\hline 1950 & 33.75 & 46.18 & 50.25 & 35.18 & 35.68 & 46.58 & 47.87 & 33.84 & 44.00 \\
\hline 1960 & 34.91 & 48.71 & 54.15 & 37.87 & 37.89 & 44.16 & 48.95 & 35.58 & 44.53 \\
\hline 1970 & 35.30 & 50.31 & 56.36 & 39.89 & 38.06 & 38.56 & 49.95 & 37.98 & 45.78 \\
\hline 1980 & 35.12 & 50.35 & 56.50 & 40.37 & 36.56 & 35.83 & 50.17 & 38.68 & 46.84 \\
\hline 1990 & 35.20 & 49.92 & 55.52 & 39.86 & 34.50 & 33.70 & 50.85 & 39.28 & 48.28 \\
\hline 2000 & 35.23 & 49.47 & 55.14 & 39.11 & 32.39 & 31.96 & 50.89 & 39.57 & 48.53 \\
\hline
\end{tabular}

Source: Calculated from Swiss population data from the Swiss Federal Statistics Office.

only the largest populations, but also major cities that are economic, political, and social centers.

Table 2. Cantons and Changes in Hoover Index 1970-2000

\begin{tabular}{|l|r|r|r|}
\hline $\begin{array}{l}\text { Overall Change in Hoover } \\
\text { Index of Cantons }\end{array}$ & $\mathbf{1 9 7 0 - 8 0}$ & $\mathbf{1 9 8 0 - 9 0}$ & $\mathbf{1 9 9 0 - 0 0 - 0 0}$ \\
\cline { 2 - 4 } & -0.18 & 0.09 & 0.028 \\
\hline $\begin{array}{l}\text { Change in Hoover } \\
\text { Index by Canton: }\end{array}$ & $\mathbf{1 9 7 0 - 8 0}$ & $\mathbf{1 9 8 0 - 9 0}$ & $\mathbf{1 9 9 0 - 0 0 - 0 0}$ \\
\hline Zürich & -0.02 & -0.24 & -0.02 \\
\hline Bern & 0.13 & 0.20 & 0.29 \\
\hline Basel-City & -0.27 & -0.15 & -0.16 \\
\hline Basel-Country & 0.09 & -0.03 & -0.03 \\
\hline Vaud & 0.07 & 0.22 & 0.02 \\
\hline Aargau & 0.11 & 0.13 & 0.06 \\
\hline Geneva & 0.10 & 0.02 & 0.08 \\
\hline All other cantons & -0.39 & -0.06 & -0.22 \\
\hline
\end{tabular}

Source: Calculated from Swiss population data from the Swiss Federal Statistics Office.
At the district level (Table 1), we find different population patterns than at the cantonal level. The concentration level, as measured by the Hoover Index, is much higher (41.00-50.35 compared to 31.56-35.30). There was minor concentration in the 1970 s while there is clear indication of deconcentration in the 1980s and 1990s. This differs from what was happening in many other developed countries. In the United States, for example, the county based Hoover Index decreased in the 1970s, increased in the 1980s and decreased again by a small amount in the 1990s [20].

Fig. (4) illustrates how districts fared when grouped by population size over the 50 year period from 1950 to 2000 (see also Tables $\mathbf{A 2}$ and $\mathbf{A 3}$ ). The districts are separated into four groups depending on their population size in 2000: less than 10,000 (26 districts), 10,000-50,000 (111 districts), 50,000-100,000 (23 districts), above 100,000 (16 districts). In the aggregate, districts with the largest populations were growing at a rate above the national average in the 1950s, whereas the smallest districts were growing at the slowest pace. Starting in the 1960s, the number of districts growing

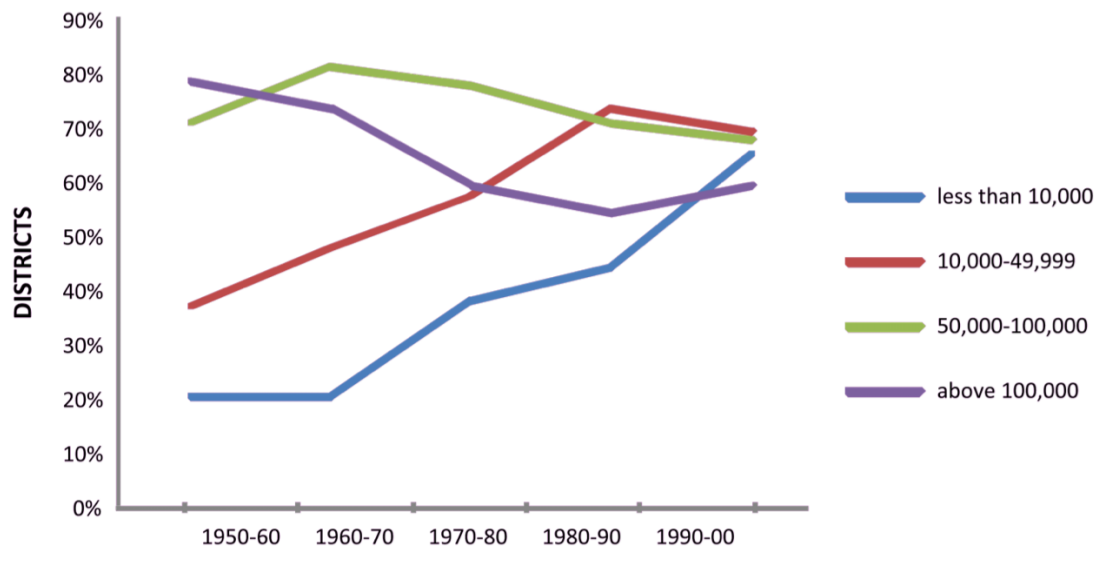

Fig. (4). Percentage of Swiss Districts Growing Above National Average 1950-2000. 
above the national average declined continuously until the 1990s, and the relative success of two smallest groups of districts improved significantly. The majority of the sparsely populated districts had started below the national average, but experienced a sharp upward trend after the 1950s, indicating a trend away from large, densely populated districts toward sparsely and medium sized districts. We discern no geographical trend in terms of the big losers during 1970-2000, except that most of the districts that include the big cities like Zurich $(-30.3 \%)$, Basel-City $(-36.2 \%)$, and Bern $(-20.4 \%)$ were among the major losers. The biggest gainers were located in the cantons of Vaud and Zurich (outside the city's political borders). In the district of Geneva, the district as whole grew by $19.00 \%$, while the City of Geneva recorded only $2.5 \%$, growth below the national average of $16.52 \%$. Among possible reasons for these developments are the very high costs of housing and developable land in the major cities, combined with a significant increase in housing consumption (in square meters $\mathrm{m}^{2}$ ) per capita.

The regional Hoover Index is presented in Table 1. The regional population concentration/deconcentration trend was not uniform during the $20^{\text {th }}$ century. The only uniform pattern observed is the deconcentration during the 1980s and 1990s in the Lake Geneva, Espace Mittelland, Northwestern Switzerland, and Zurich regions. These four regions occupy $40 \%$ of the land and are home to $72 \%$ (year 2000) of the population. Starting from 1960 s, we see population concentration in the regions of Eastern Switzerland, Central Switzerland, and Tessin. In the 1970s both the regions of Zurich and the Northwestern Switzerland region (Basel-City is the regional center), experienced deconcentration. As discussed above, the national deconcentration during the 1970s was mainly due to the demographic change in these two big regions. The Central Switzerland region experienced deconcentration once in the 1930s, as a result of a poor economy that was hit especially hard by the Great Depression. In the Tessin region, which consists of the Canton of Tessin, deconcentration in the 1940s can likely be attributed to the negative impact of World War II on this region. The deconcentration in the 1980s 1990s in the districts can be related to deconcentration in the four big regions of Lake Geneva, Espace Mittelland Northwestern Switzerland, and Zurich, although some large cities in this region are starting to show signs of renewed population growth, as predicted by Schaeffer [43].

This research also explores the distribution patterns of Swiss and foreign nationals respectively, for 1970-2005. The immigrant population increased in size from $11.6 \%$ at the beginning of last century to $20.7 \%$ in 2005 . The number of foreign nationals for 2005 is based on actual statistical information, while the information on their distribution by region in that year is based on a forecast by the Swiss Federal Office of Statistics. From 1984-2005, the immigrant population grew at an average annual rate of $2.25 \%$. During this period the average annual growth rate for Swiss citizens was $0.35 \%$ (Fig. A1). Thus, immigrants were the driving force of national population growth. The majority of immigrants are of European origins (close to $80 \%$ ) and lives in the cantons of Zurich, Geneva, Vaud, and Bern.
Table 3. Hoover Index by Citizenship

\begin{tabular}{|l|c|c|c|}
\hline Year & Total Population & Swiss Citizens & Foreign Nationals \\
\hline \hline 1970 & 35.18 & 34.61 & 44.88 \\
\hline 1975 & 34.97 & 34.41 & 44.47 \\
\hline 1980 & 34.89 & 34.25 & 45.51 \\
\hline 1985 & 34.77 & 33.95 & 44.81 \\
\hline 1990 & 34.74 & 33.63 & 44.01 \\
\hline 1995 & 34.81 & 33.07 & 42.42 \\
\hline 2000 & 34.97 & 32.99 & 43.08 \\
\hline 2005 & 35.12 & 33.06 & 43.31 \\
\hline
\end{tabular}

The Hoover Index for Swiss citizens decreased steadily from 1975 until 2000 (Table 3), indicating deconcentration. In the $21^{\text {st }}$ century the trend reversed and the Hoover Index increased. For foreign nationals there is no clear trend. Deconcentration occurred during 1970-1975 and 1980-1995 while concentration was recorded during 1975-1980 and 2000-2005.

The Hoover Index of total population shows much smaller fluctuations than the index of each group. This indicates that the foreign population, which increased by $53.90 \%$ between 1970 and 2005, did influence the national population distribution pattern, but their influence was much smaller than that of natives, as measured by the respective correlation coefficients of the Hoover Index of each group with the Hoover Index of the total population $(0.058$ and 0.180 , respectively). Of course, their smaller influence of foreign $v s$ Swiss nationals is a reflection of the former's smaller size.

The particular focus of this study is the population pattern between 1970 and 2000. The national index shows deconcentration at the cantonal level in the 1970s, while at the district level deconcentration started a bit later, in the 1980s and 1990s. The regional Hoover Index gives a mixed picture. Major population centers show a pattern of deconcentration during the 1970s, 1980s, and 1990s and sparsely populated regions show a pattern of regional concentration.

\subsection{Counter-urbanization}

Table 4 and Fig. (5) show the correlation between density, and population growth at the cantonal level. The correlation coefficient was strongly positive until the 1970s. At the district level the correlation dropped just below zero in the 1960s already. From 1970 until 2000 it was negative, indicating counter-urbanization. A closer look at the data by canton reveals a clear outlier, however. Basel-City with a population density of over $5,000 / \mathrm{km}^{2}$ has a disproportionate influence on the correlation, coefficient. Between 1970 and 2000 its population density declined from $6,349.9 / \mathrm{km}^{2}$ to $5,083.2 / \mathrm{km}^{2}$. When we combined Basel-City and BaselCountry (both of them were once one canton and the latter is the "natural" hinter land of the former) and recalculated the 
Table 4. Correlation Between Deviation from National Average of Density and Population Growth

\begin{tabular}{|c|c|c|c|c|c|c|c|c|c|c|}
\hline & $1900-10$ & 1910-20 & 1920-30 & $1930-41$ & 1941-50 & $1950-60$ & $1960-70$ & $1970-80$ & $1980-90$ & 1990-00 \\
\hline All Cantons & 0.998 & 0.923 & 0.975 & 0.987 & 0.999 & 0.987 & 0.707 & -0.953 & -0568 & -0.762 \\
\hline BSBL Combined & 0.943 & 0.811 & 0.336 & 0.546 & 0.984 & 0.977 & 0.953 & 0.492 & 0.872 & 0.824 \\
\hline All Districts & 0.972 & 0.935 & 0.289 & 0.582 & 0.991 & 0.959 & -0.0005 & -0.919 & 0.661 & 0.323 \\
\hline Districts w/o BS and City of Geneva & 0.893 & 0.836 & 0.805 & 0.922 & 0.968 & 0.854 & 0.138 & -0.730 & 0.054 & -0.084 \\
\hline
\end{tabular}

correlation, the coefficient stayed positive, though it declined in size.

At the district level, we found a strong urbanization pattern that lasted until about 1960. Then there were two decades of counter-urbanization before urbanization returned in 1980 through 2000. The urbanization trend was relatively strong during 1980-1990, but decreasing during 1990-2000 (Table 4). In this case, however, there are two outliers. One is once again the Canton of Basel-City (BS) and the other is the City of Geneva. The Canton of Geneva occupies a very small territory and hence the canton also serves as the district. For this study we divided the district/canton into the City of Geneva and the rest of the district/canton. In 1970, the population density of the city was above $10,000 / \mathrm{km}^{2}$ compared to 687 in the rest of the district. The coefficient was recalculated without Basel-City and the City of Geneva. Even with the deletion of these two outliers, we see a strong counter-urbanization trend during 1970-80, a weak urbanization in 1980-90, and weak counter-urbanization in the 1990-00 period.

The population loss of in major cities could indicate either counter-urbanization or sub-urbanization, because the losses occurred within the cities' political boundaries while the economic, social, and cultural influence of these major cities reaches much further. However, the population losses of almost all Swiss cities with a population above 30,000 between 1970 and 2000 add to the evidence for counterurbanization (Appendix, Table A4). These cities lost a combined total of 184,586 people, most of them $(88 \%)$ during 1970-80. In other words, the losses were not limited to the largest cities. Geneva stood out from among the five largest cities (populations above 100,000). While it lost population during 1970-80, it gained population during the final two decades of the last century.
Comparing urban and rural population growth from 1900-2000, we see a clear shift in growth patterns, which began during 1960-70. Prior to the 1960s, the urban population grew above national and rural growth rates. During the 1960s rural population growth exceeded urban growth for the first time. A more detailed look at the data provides additional information. In Switzerland, urban communities are divided into three groups: core city (Kernstadt einer Agglomeration), other metropolitan communities (andere Agglomerationsgemeinden), and isolated cities (isolierte Städte). If we compare these three urban groups with the rural group (ländliche Gemeinden), we see that at the end of the century core urban areas experienced the slowest growth rates. Smaller urban communities close to the core cities (suburbs) started to grow faster than the latter during the 1950s, indicating suburbanization (Fig. 6). Growth in rural areas started to surpass that of core cities in the 1970s, indicating some counter-urbanization occurring simultaneously with suburbanization. The minor counter-urbanization during the 1970s that was identified by Schaeffer [1] continued until the end of the century.

\subsection{Trend Reversal}

The trend reversal indexes at the cantonal level (Table 5) show that the smallest change in population distribution occurred during the 1941-50 and 1990-2000 periods. The changes of the 1970 s were also relatively small. There is a clear decline in the magnitude of the change starting in the 1960s. At the cantonal level, the index was steadily increasing during the study period 1900-2000 though after the $1960 \mathrm{~s}$, the increases were becoming smaller. The slowdown is particularly apparent for the last decade (Table $\mathbf{5}$, trend reversal by decade).

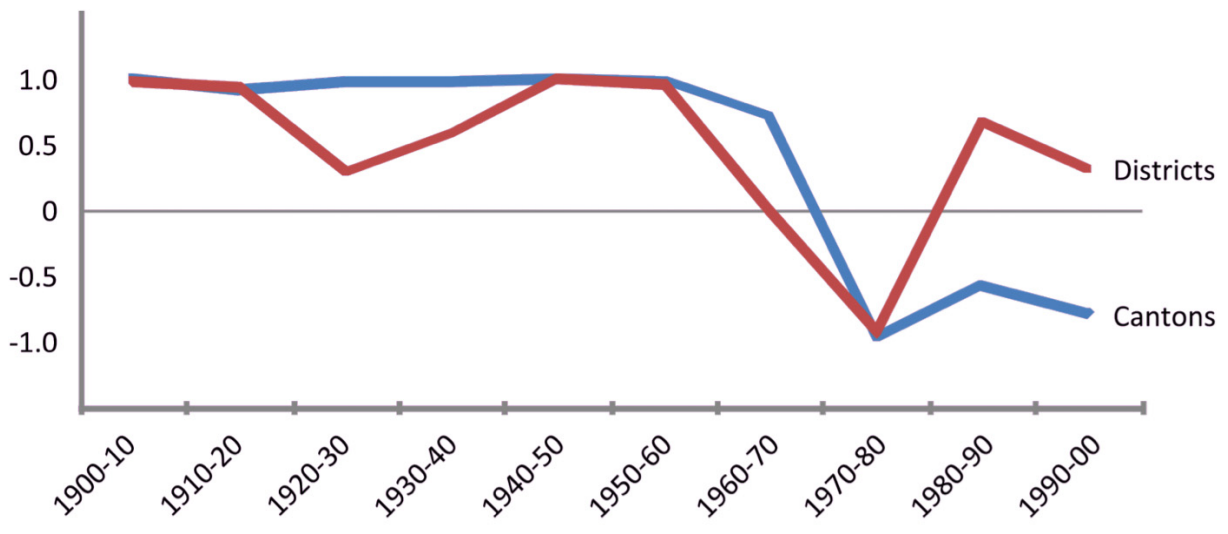

Fig. (5). Comparison of correlation between districts and contons. 


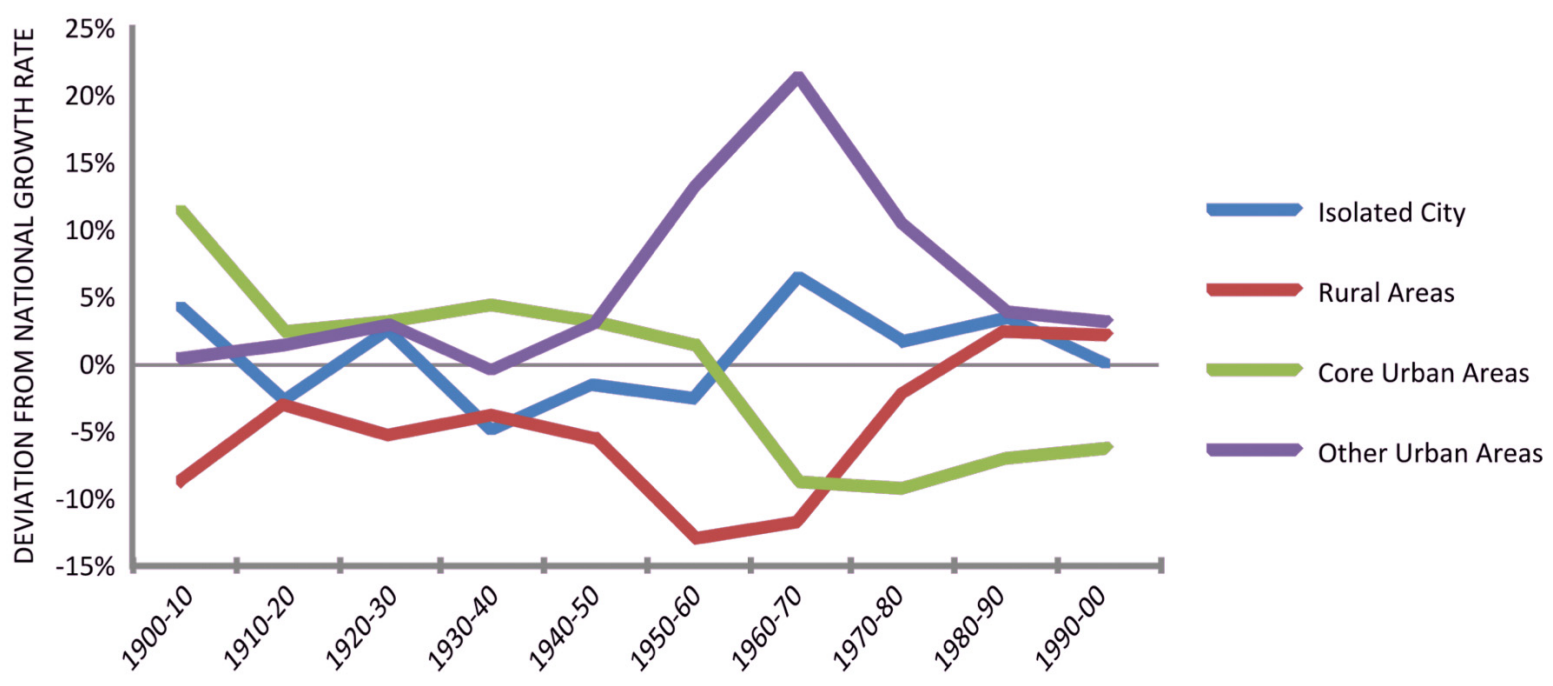

Fig. (6). Comparison of population growth.

There is some evidence of trend reversal, defined as a decline in the overall index at the district level, where the cumulative index declined in the 1980. However, it grew again in the 1990s and reached its highest level yet. Therefore, the evidence suggesting a trend reversal is very weak since the index declined only during one decade and then increased again. Hence, although there is some evidence of counter-urbanization, the evidence during the $20^{\text {th }}$ Century does not suggest a trend reversal.

\section{SUMMARY AND CONCLUSIONS}

This study provides evidence of deconcentration and counter-urbanization in Switzerland during the second half of the last century. Different Swiss regions experienced deconcentration during different periods, which is why the national Hoover index alone does not give a clear picture of the population distribution pattern. The results also show a trend of moving away from large densely populated districts and towards smaller, more sparsely populated and medium sized districts. Although the foreign population doubled in size in the last century, its role in shaping in the country's population distribution is fairly low.

Suburbanization and counter-urbanization were occurring and core urban centers were growing slower than smaller urban and rural areas. During the last decade of the century, most major (core) cities lost population to smaller urban and rural areas. The cantons of Aargau, Vaud, Ticino, Thurgau, and Fribourg were net gainers from internal migration, while Basel-City, Grison, Bern, Geneva, and St. Gall were the biggest losers. The Zurich MSA was the dominant destination of international net migration. There is little evidence of trend reversal as defined in this study.

This study did not analyze causes for population deconcentration and counter-urbanization, but the analysis provided descriptive statistics, which allowed us to identify the regions where concentration, deconcentration, and counter-urbanization were occurring. It is safe to say that a significant part of the growth in the cantons of Aargau and Schwyz during the last few decades is the result of increases in the population and geographic size of the Zurich metropolitan region (Agglomeration Zürich), in no small part because investments into transportation infrastructure (interstates, public transportation, in general, and commuter train lines, in particular) significantly reduced commuting times, making living in distant communities more desirable. In addition to Aargau and Schwyz, the Canton of Thurgau benefitted from these investments, and the cities of Zug and Lucerne also see a significant flow of daily commuter traffic between themselves and the Zurich metropolitan region. Similar trends are visible in other metropolitan regions,

Table 5. Trend Reversal (TR)

\begin{tabular}{|c|c|c|c|c|c|c|c|c|c|c|}
\hline \multicolumn{11}{|c|}{ TR by Decade $\left(\mathrm{TR}_{\mathrm{it}+10}\right)$} \\
\hline TR Districts & 0.04519 & 0.02679 & 0.03520 & 0.03132 & 0.02159 & 0.04371 & 0.05388 & 0.03875 & 0.02783 & 0.02557 \\
\hline \multicolumn{11}{|c|}{ Cumulative TR (TR $\left.{ }_{1900 t}\right)$} \\
\hline TR Canton & 0.12345 & 0.17918 & 0.31167 & 0.38409 & 0.46121 & 0.63823 & 0.71346 & 0.73023 & 0.75567 & 0.80698 \\
\hline TR Districts & 0.04519 & 0.05604 & 0.08076 & 0.10332 & 0.12035 & 0.15600 & 0.17554 & 0.18332 & 0.18254 & 0.18605 \\
\hline
\end{tabular}


though they are not (yet?) as pronounced. This suggests that internal and external push and pull factors shape the population distribution pattern, and the study of differential counter-urbanization [44] could yield additional insights. The study has several implications. First, even with all the improvements in infrastructure and advances in technology, the topography of the county is still dictating the overall population distribution. As shown in Figs. $(2,3)$, population patterns in mountain regions have not changed much. They are populated in a linear fashion in the valleys. Second, in Switzerland, different regions of the country experienced deconcentration at different periods. In a multi-cultural country like Switzerland, policy related to population distribution has to take account of differences in the regions. National population distribution analysis masks these differences and one must be cautious using it in policy development.

\section{ACKNOWLEDGEMENTS}

We acknowledge partial support for this research from the West Virginia Agricultural and Forestry Experiment Station and from the Regional Research Institute. Comments by anonymous referees and guidance from the editor have resulted in improvements over an earlier version of this article. The usual caveat applies.

\section{APPENDIX}

Table A.1. Deviations from National Population Growth Rates by Canton 1900-2000

\begin{tabular}{|c|c|c|c|c|c|c|c|c|c|c|}
\hline Canton & $1900-10$ & $1910-20$ & $1920-30$ & $1930-40$ & $1940-50$ & $1950-60$ & $1960-70$ & $1970-80$ & $1980-90$ & $1990-00$ \\
\hline National Growth Rate & 13.21 & 3.38 & 4.80 & 4.90 & 10.53 & 15.14 & 15.49 & 1.53 & 7.98 & 6.03 \\
\hline 1. Zurich & 3.70 & 3.50 & 9.89 & 4.29 & 4.66 & 7.42 & 0.84 & -0.18 & -2.97 & -0.19 \\
\hline 2. Bern & -2.85 & 1.58 & -2.07 & 1.36 & -0.14 & -3.93 & -4.66 & -1.90 & -3.00 & -4.54 \\
\hline 3. Lucerne & 0.92 & 2.51 & 2.16 & 4.19 & -2.48 & -1.62 & -1.20 & 0.72 & 2.19 & 1.40 \\
\hline 4. Uri & -0.96 & 5.03 & -8.99 & 13.97 & -5.94 & -3.01 & -9.02 & -2.14 & -7.02 & -4.36 \\
\hline 5. Schwyz & -7.71 & -1.15 & -0.43 & 1.87 & -3.73 & -5.34 & 2.48 & 4.20 & 7.03 & 8.92 \\
\hline 6.a Obwalden & -0.75 & -1.02 & 5.64 & -0.06 & -1.76 & -10.58 & -9.55 & 4.00 & 4.24 & 5.69 \\
\hline 6.b Nidwalden & -7.71 & -2.17 & 3.08 & 10.33 & 1.23 & -0.71 & 0.05 & 10.10 & 7.49 & 6.66 \\
\hline Glarus & -10.22 & -1.83 & 0.58 & -7.38 & -2.22 & -8.55 & -20.45 & -5.30 & -3.10 & -6.87 \\
\hline 8. Zug & -1.00 & 8.74 & 4.16 & 1.63 & 4.74 & 9.12 & 14.06 & 10.13 & 4.69 & 10.93 \\
\hline 9. Fribourg & -4.06 & -0.95 & -4.67 & 1.26 & -6.16 & -14.83 & -2.22 & 1.20 & 7.31 & 7.15 \\
\hline 10. Solothurn & 2.95 & 8.22 & 5.60 & 2.55 & -0.49 & 2.63 & -3.87 & -4.22 & -1.72 & -0.59 \\
\hline 11.a Basel-City & 7.90 & 0.14 & 5.38 & 4.73 & 5.08 & -0.34 & -11.34 & -14.74 & -10.18 & -11.71 \\
\hline 11.b Basel-Country & -1.60 & 3.63 & 7.09 & -2.64 & 3.07 & 20.54 & 20.95 & 4.99 & -1.53 & -1.65 \\
\hline 12. Schaffhausen & -2.17 & 6.01 & -3.29 & 0.15 & -3.57 & -0.43 & -5.07 & -6.26 & -4.02 & -4.32 \\
\hline 13.a Appenzell I. Rh. & -4.61 & -3.69 & -9.08 & -9.23 & -10.2 & -18.75 & -14.09 & -3.67 & 0.01 & -0.63 \\
\hline 13.b Appenzell A. Rh. & -8.34 & -7.90 & -16.32 & -13.52 & -3.42 & -13.1 & -15.28 & -4.41 & 1.72 & -3.59 \\
\hline 14. Saint Gall & 7.81 & -5.81 & -7.90 & -4.96 & -2.53 & -5.32 & -2.23 & 0.42 & 1.08 & -0.1 \\
\hline 15. Grisons & -1.20 & -1.01 & 0.62 & -3.39 & -3.63 & -7.59 & -5.57 & 0.04 & -2.36 & 1.54 \\
\hline 16. Aargau & -1.52 & 1.01 & 3.04 & -0.73 & 0.68 & 4.86 & 4.56 & 3.12 & 3.95 & 1.85 \\
\hline 17. Thurgau & 5.96 & -2.63 & -4.70 & -3.39 & -2.12 & -4.00 & -5.62 & -1.01 & 5.93 & 3.29 \\
\hline 18. Tessin & -0.56 & -5.89 & -0.22 & -3.23 & -2.40 & -3.43 & 10.03 & 6.79 & -1.85 & 2.71 \\
\hline 19. Vaud & -0.38 & -3.37 & -0.27 & -1.42 & -0.58 & -1.39 & 3.68 & 1.77 & 5.84 & 0.43 \\
\hline 20. Valais & -1.02 & -3.49 & 1.56 & 3.84 & -3.21 & -3.46 & 0.70 & 4.35 & 6.25 & 3.01 \\
\hline 21. Neuchatel & -7.84 & -4.67 & -10.14 & -10.07 & -1.84 & 0.06 & -0.90 & -7.92 & -4.43 & -3.61 \\
\hline 22. Geneva & 3.61 & 7.01 & -4.58 & -2.87 & 5.52 & 12.61 & 12.43 & 3.73 & 0.66 & 3.07 \\
\hline 23. Jura & -10.96 & -3.86 & -9.66 & -3.58 & -5.08 & -8.40 & -9.58 & -5.01 & -6.06 & -3.02 \\
\hline
\end{tabular}

Source: Calculated from Swiss population data from the Swiss Federal Office for Statistics.

Note: The cantons are listed in the order in which they are mentioned in the Swiss constitution. Six regions-Basel-City and Basel-Country Obwalden and Nidwalden and Appenzell Inner. Rhoden and Appenzell Ausser Rhoden-arc considered half-cantons for political representation in the federal parliament's senate (Ständerat). That is each half-canton can send one senator while the full-cantons send two. 
(APPENDIX) contd.....

Table A.2. Percentage of Districts Growing Above National Average

\begin{tabular}{|l|c|c|c|c|c|}
\hline District by Population in 2000 & $\mathbf{1 9 5 0 - 6 0}$ & $\mathbf{1 9 6 0 - 7 0}$ & $\mathbf{1 9 7 0 - 8 0}$ & $\mathbf{1 9 8 0 - 9 0}$ & $\mathbf{1 9 9 0 - 0 0}$ \\
\hline \hline$<\mathbf{1 0 0 0 0}$ & 0.00 & 0.00 & 23.08 & 30.77 & 57.69 \\
\hline $\mathbf{1 0 0 0 0 - 5 0 0 0 0}$ & 21.62 & 35.14 & 47.75 & 68.47 & 63.06 \\
\hline $\mathbf{5 0 0 0 0 - 1 0 0 0 0 0}$ & 65.22 & 78.26 & 73.91 & 65.22 & 60.87 \\
\hline$>\mathbf{1 0 0 0 0 0}$ & 75.00 & 68.75 & 50.00 & 43.75 & 50.00 \\
\hline
\end{tabular}

Source: Calculated from Swiss population data from the Swiss Federal Statistics Office.

Table A.3. Deviation from Swiss Population Growth

\begin{tabular}{|c|c|c|c|c|c|c|c|c|c|c|}
\hline & $\mathbf{1 9 0 0 - 1 0}$ & $\mathbf{1 9 1 0 - 2 0}$ & $\mathbf{1 9 2 0 - 3 0}$ & $\mathbf{1 9 3 0 - 4 0}$ & $\mathbf{1 9 4 0 - 5 0}$ & $\mathbf{1 9 5 0 - 6 0}$ & $\mathbf{1 9 6 0 - 7 0}$ & $\mathbf{1 9 7 0 - 8 0}$ & $\mathbf{1 9 8 0 - 9 0}$ & $\mathbf{1 9 9 0 - 0 0}$ \\
\hline \hline Rural & -8.62 & -3.02 & -5.21 & -3.76 & -5.59 & -12.90 & -11.61 & -2.18 & 2.43 & 2.16 \\
\hline Urban & 6.22 & 1.90 & 3.14 & 2.09 & 2.93 & 6.26 & 4.75 & 0.77 & -0.83 & -0.76 \\
\hline
\end{tabular}

Source: Calculated from Swiss population data from the Swiss Federal Statistics Office.

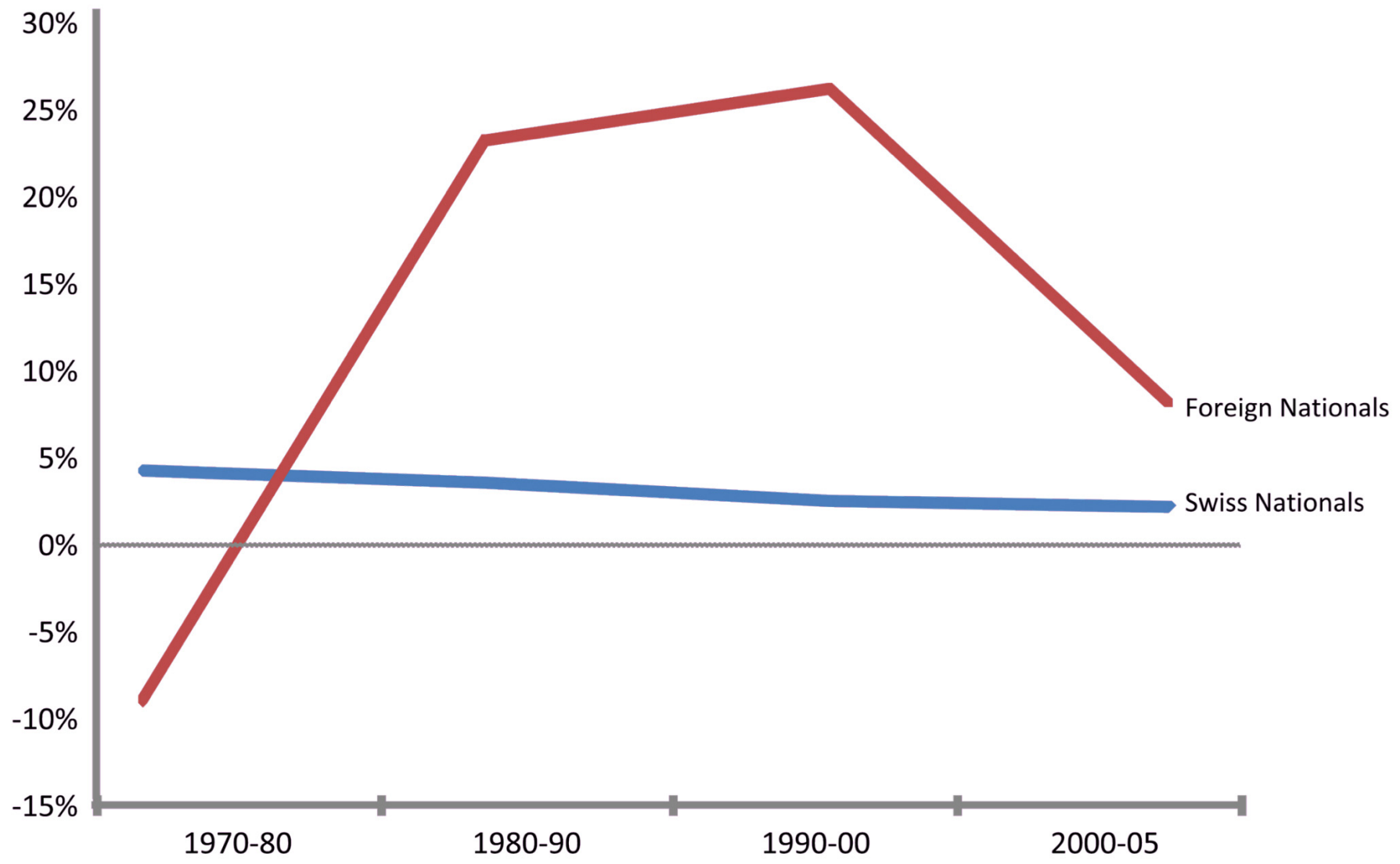

Fig. (A1). Population growth rates, 1970-2005. 
Table A4. Population Change in Major Cities*

\begin{tabular}{|c|c|c|c|c|c|c|}
\hline \multirow{2}{*}{ Cities } & \multicolumn{3}{|c|}{ Percentage Change } & \multicolumn{3}{|c|}{ Absolute Change } \\
\hline & $1970-80$ & $1980-90$ & $1990-00$ & 1970-80 & $1980-90$ & $1990-00$ \\
\hline Zurich & -12.57 & -1.21 & -0.48 & -53118 & -4479 & -1770 \\
\hline Geneva & -9.86 & 9.29 & 4.05 & -17113 & 14537 & 6922 \\
\hline Basel & -14.43 & -2.04 & -6.65 & -30714 & -3715 & -11870 \\
\hline Bern & -10.56 & -6.14 & -5.65 & -17151 & -8916 & -7704 \\
\hline Lausanne & -7.30 & 0.60 & -2.50 & -10034 & 763 & -3198 \\
\hline Winterthur & -6.43 & 0.23 & 4.05 & -5964 & 201 & 3524 \\
\hline St. Gall & -6.19 & -0.80 & -3.47 & -5005 & -610 & -2611 \\
\hline Luzern & -9.45 & -3.55 & -2.52 & -6601 & -2244 & -1538 \\
\hline Biel & -16.38 & -3.53 & -6.24 & -10540 & -1900 & -3238 \\
\hline Thun & 1.01 & 3.58 & 5.67 & 368 & 1320 & 2166 \\
\hline Köniz & 2.88 & 11.57 & 1.27 & 936 & 3868 & 473 \\
\hline La Chaux-de-Fonds & -12.07 & -0.91 & 0.33 & -5113 & -340 & 122 \\
\hline Schaffhausen & -7.52 & -0.07 & -1.74 & -2785 & -25 & -597 \\
\hline Freiburg & -5.78 & -2.79 & -2.22 & -2295 & -1045 & -808 \\
\hline Chur & 2.71 & 2.59 & 0.37 & 844 & 831 & 121 \\
\hline Neuenburg & -11.23 & -2.47 & -1.98 & -4356 & -849 & -665 \\
\hline Vernier & 25.78 & 1.86 & 3.78 & 5732 & 520 & 1077 \\
\hline \multirow{2}{*}{ All major cities } & \multicolumn{3}{|c|}{ Average } & \multicolumn{3}{|c|}{ Total } \\
\hline & -7.70 & 0.27 & -1.11 & -162909 & -2083 & -19594 \\
\hline
\end{tabular}

Source: Calculated from Swiss population data from the Swiss Federal Statistics Office.

*Population $>30000$.

\section{REFERENCES}

[1] Schaeffer PV. Deconcentration counterurbanization or trend reversal? The population distribution of Switzerland 1900-1980. Socio-Econ Plan Sci 1992; 26(2): 89-102.

[2] Champion T, Hugo G. Eds. New forms of urbanization: beyond the urban-rural dichotomy. Aldershot United Kingdom: Ashgate 2004.

[3] Garreau J. Edge City: life on the new frontier. Norwell MA: Anchor Press 1991.

[4] Wehrwein GS. The rural-urban fringe. Econ Geog 1942; 18(3): 217-28.

[5] Castle EN. Eds. The changing American countryside: rural people and places. Lawrence KS: University Press of Kansas 1995.

[6] Arwood DE. Decentralization. In: Goreham GA, Ed. Encyclopedia of rural America: the land and people. $2^{\text {nd }}$ ed. Millerton NY: Grey House Publishing 2008; pp. 245-47.

[7] Champion AG. Recent changes in the pace of population deconcentration in Britain. Geoforum 1987; 18(4): 379-401.

[8] Champion AG, Ed. Counterurbanization: the changing pace and nature of population deconcentration. Edward Arnold London 1990.

[9] Champion AG. Population change and migration in Britain since 1981: evidence for continuing deconcentration. Environ Plan A 1994; 26: 1501-20.

[10] Fielding AJ. Counterurbanization in Western Europe. Prog Plan 1982; 17: 1-52.

[11] Fielding AJ. Migration and counterurbanization in Western Europe since 1950. Geog J 1989; 155: 60-9.

[12] Frey WH. 1988. The Re-emergence of core region growth: a return to the metropolis? Inter Reg Sci Rev 1988; 11:261-7.
[13] Frey WH, Speare A. The revival of metropolitan population growth in the United States: An assessment of findings from the 1990 Census. Popul Dev Rev 1992; 18 (1): 129-46.

[14] Jones H, Ford N, Caird J, Berry W. Counterurbanization in societal context: long-distance migration to the highlands and islands of Scotland. Prof Geogr 1984; 36: 437-44.

[15] Kanaroglou P, Braun G. The pattern of counterurbanization in the Federal Republic of Germany. Prof Geogr 1992; 38: 170-81.

[16] Kontuly T, Vogelsang R. Explanations for the intensification of counterurbanization in the Federal Republic of Germany. Prof Geogr 1988; 40: 42-53.

[17] Kontuly T, Wiard S, Vogelsang R. Counterurbanization in the Federal Republic of Germany. Prof Geogr 1986; 38: 170-81.

[18] Kontuly T, Braun GO. The pattern of counterurbanization in the Federal Republic of Germany 1977-85. Environ Plan A 1992; 24(4): 481-96.

[19] Kontuly T, Schon KP. Changing Western German internal migration systems during the second half of the 1980s. Environ Plan A 1994; 26: 1521-43.

[20] Long L. Nucci A. The Hoover Index of population concentration: A correction and update. Prof Geogr 1997; 49: 431-40.

[21] Long L. Nucci A. The 'clean break' revisited: Is US population again deconcentrating? Environ Plan A 1997; 29 (8): 1355-66.

[22] Meijers E. Summing small cities does not make a large city: polycentric urban regions and the provision of cultural leisure and sports Amenities. Urban Stud 2008; 45(11): 2323-42.

[23] Schneider A, Woodcock CE. Compact dispersed fragmented extensive? A comparison of urban growth in twenty-five global cities using remotely sensed data pattern metrics and census information. Urban Stud 2008; 45(3): 659-92.

[24] Bourne LS. Alternative perspectives on urban decline and population deconcentration. Urban Geog 1980; 1(1): 39-52. 
[25] Lin GCS. Metropolitan development in a transitional socialist economy: spatial restructuring in the Pearl River Delta China. Urban Stud 2001; 38(3): 383-406.

[26] Feng J, Wang F, Zhou Y. The spatial restructuring of population in metropolitan Beijing: toward polycentricity in the post-reform era. Urban Geog 2009; 30(7): 779-802.

[27] Lattes A. Population distribution in Latin America: Is there a trend towards population deconcentration? In: population distribution and migration. Proceedings of the united nations expert group meeting on population distribution and migration Santa Cruz Bolivia 18-22 January 1993. Convened in preparation for the international conference on population and development Cairo 5-13 September 1994 compiled by United Nations. Department of Economic and Social Affairs. Population Division. New York New York United Nations 1998; pp. 117-36.

[28] Bontje M. Dealing with deconcentration: population deconcentration and planning response in polynucleated urban regions in north-west Europe. Urban Stud 2001; 38(4): 769-85.

[29] Henrie CJ, Plane DA. Decentralization of the nation's main street: new coastal-proximity-based portrayals of population distribution in the United States 1950-2000. Prof Geogr 2006; 58(4): 448-59.

[30] Center for the study of rural America. New governance for a new rural economy: Reinventing public and private institutions. Kansas City KS: Federal Reserve Bank of Kansas City 2004.

[31] OECD. The new rural paradigm: policies and governance. Paris: organization for economic co-operation and development 2006.

[32] Mitchell CJA. Making sense of counterurbanization. J Rural Stud 2004; 20: 15-34

[33] OECD. Switzerland. In international migration outlook: SOPEMI. Paris: organization for economic co-operation and development. 2008; pp. 282-3.

[34] OECD. Regional problems and policies in Switzerland. Paris: organization for economic co-operation and development, 1991.
[35] Glanzmann Lars Nathalie Grillon Christian Kruse and Alain Thierstein. Northern Switzerland: Commuting and the definition of functional urban regions. Institute for Community Studies/The Young Youndation and Polynet Partners 2005. Available from: http://www.polynet.org.uk/docs/1_1_n_switz.pdf [Accessed: 05/15/ 2009].

[36] Swiss Federal Government 1979 2008. Bundesgesetz über die Raumplanung (RPG) of June 221979 revised August 12008 Swiss Federal Government Bern Switzerland (1979). Available from: http://www.admin.ch/ch/d/sr/7/700.de.pdf [Accessed: 04/02/2009].

[37] Swiss Federal Council 2005. Botschaft über die neue Regionalpolitik (NRP). Available from: http://www.newsservice.admin.ch/NSBSubscriber/message/attachments/7629.pdf [Accessed: 04/02/2009].

[38] Swiss Federal Government 2006. Bundesgesetz über die Regionalpolitik. Available from: http://www.admin.ch/ch/d/sr/7/ 700.de.pdf [Accessed: 04/02/2009].

[39] Flückiger H, Frey RL, Gmünder Ma. Eds. Schweizerische raumordnungspolitik im integrierten Europa: beiträge aus dem forum für raumordnung 2000/2001. Basel Switzerland: Wirtschaftswisschenschaftliches Zentrum der Universität Basel 2001.

[40] Dean KG, Brown BJH, Perry RW, Shaw DP. The conceptualisation of counterurbanisation. Area 1984; 16(1): 9-14.

[41] Berry BJL. The Counterurbanization process: urban America since 1970. Urban Aff Ann Rev 1976; 11: 17-30.

[42] Swiss Federal Office of Statistics Statistics: Statistical Lexicon accessed in 2008. Available from: http://www.bfs.admin.ch/bfs/po rtal/de/index/infothek/lexikon [Accessed: 08/12/2009].

[43] Schaeffer PV. Auswirkungen demographischer Entwicklung auf das Städtewachstum. Schweizerische Zeitschrift für Volkswirtschaft und Statistik 1992; 128(3): 369-81.

[44] Kontuly TG, Hermanus S. Introduction to special issue: testing the differential urbanization model in developed and less developed countries. J Econ Soc Geogr 2003; 94: 3-10.

Received: September 21, 2009

Revised: March 12, 2010

Accepted: April 8, 2010

(C) Kahsai and Schaeffer; Licensee Bentham Open.

This is an open access article licensed under the terms of the Creative Commons Attribution Non-Commercial License (http://creativecommons.org/licenses/by$\mathrm{nc} / 3.0 /$ ) which permits unrestricted, non-commercial use, distribution and reproduction in any medium, provided the work is properly cited. 